\title{
Landslides and Debris Flows in Ephraim Canyon, Central Utah
}

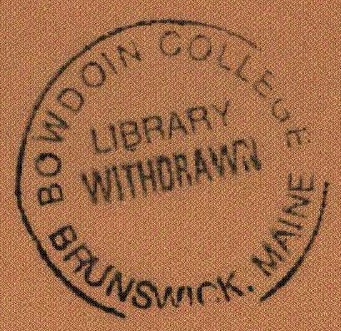

\section{U.S. GEOLOGICAL SURVEY BULLETIN 1842-C}



Chapter C

\title{
Landslides and Debris Flows in Ephraim Canyon, Central Utah
}

\author{
By REX L. BAUM and ROBERT W. FLEMING
}

Geologic mapping of landslides in bedrock, landslides in unconsolidated materials, and debris flows occurring in 1983-1986, on the west side of the Wasatch Plateau

\section{U.S. GEOLOGICAL SURVEY BULLETIN 1842}

LANDSLIDE PROCESSES IN UTAH-OBSERVATION AND THEORY 
DEPARTMENT OF THE INTERIOR

MANUEL LUJAN, JR., Secretary

U.S. GEOLOGICAL SURVEY

Dallas L. Peck, Director

Any use of trade, product, or firm names in this publication is for descriptive

purposes only and does not imply endorsement by the U.S. Government.

UNITED STATES GOVERNMENT PRINTING OFFICE: 1989

For sale by the

Books and Open-File Reports Section

U.S. Geological Survey

Federal Center

Box 25425

Denver, CO 80225

\section{Lbrary of Congress Cataloging-in-Publication Data}

\section{Baum, Rex L.}

Landslides and debris flows in Ephraim Canyon, Central Utah / by Rex $L$. Baum and Robert W. Fleming.

p. $\mathrm{cm}$. - (Landslide processes in Utah-observation and theory; ch.

C) (U.S. Geological Survey bulletin ; 1842-C)

Bibliography: p.

Supt. of Docs. no.: I 19.3:1842-C

1. Landslides-Utah-Ephraim Canyon. 2. Mass-wasting-Utah-Ephraim

Canyon. I. Fleming, Robert W. II. Title. III. Series.

QE75.B9 no. 1842-C

[QE599.U5]

$557.3 \mathrm{~s}-\mathrm{dc} 19$

[551.3'53'09792]

89-600034 


\section{CONTENTS}

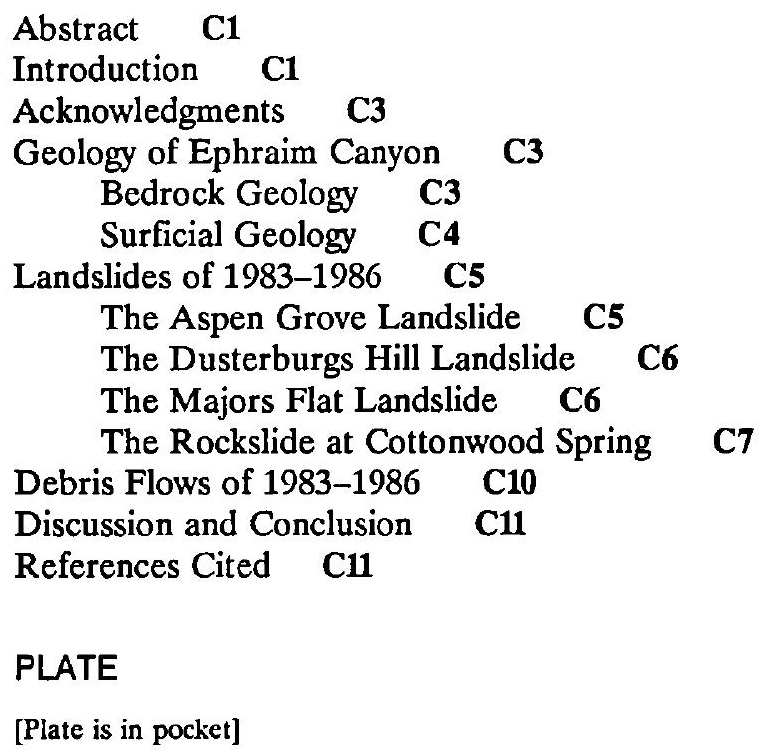

C1. Geologic map of part of Ephraim Canyon, central Utah

\section{FIGURES}

C1. Map showing location of the study area C2

C2. Photograph showing exposures of the North Horn Formation (TKn) and the Flagstaff Limestone (Tf ) on the north side of Ephraim Canyon and a rockslide on the north side of Ephraim Creek

C3. Photograph of the Dusterburgs Hill landslide, looking east from the northwest rim of New Canyon C6

C4. The Majors Flat landslide: pre-landslide topographic map; vertical aerial photograph; map showing features at surface of landslide C8

C5. Photograph showing a rockslide near Cottonwood Spring C10

C6. Photograph showing the Cottonwood Spring debris flow of $\mathbf{1 9 8 6}$ 
CONVERSION FACTORS

\begin{tabular}{lll}
\hline \multicolumn{1}{c}{ Multiply } & By & \multicolumn{1}{c}{ To obtain } \\
\hline $\mathrm{cm}$ (centimeters) & 0.3937 & in. (inches) \\
$\mathrm{m}$ (meters) & 3.2808 & $\mathrm{ft}$ (feet) \\
$\mathrm{km}$ (kilometers) & 0.6214 & $\mathrm{mi}$ (miles) \\
ha (hectares) & 2.471 & acres \\
\hline
\end{tabular}




\title{
Landslides and Debris Flows in Ephraim Canyon, Central Utah
}

\author{
By Rex L. Baum ${ }^{1}$ and Robert W. Fleming ${ }^{1}$
}

Abstract

Landslides and debris flows occurred in bedrock and surficial deposits of Ephraim Canyon, on the west side of the Wasatch Plateau, in central Utah, during the spring of 1983. The canyon walls consist of westward-dipping beds of shale, sandstone, and limestone of the North Horn Formation and the Flagstaff Limestone. Steeply dipping, north-trending, normal faults separate the rocks of the canyon walls into blocks from 0.2 to 0.5 kilometers wide. Landslide and other slope deposits mantle the bedrock in 70-80 percent of the study area.

Landslides, including rockslides, affected about 166 hectares, or about 4.7 percent of the study area. Rockslides constituted about 20 percent of this amount. Landslides in unconsolidated materials, mainly pre-1983 landslide and other slope deposits, made up the remaining 80 percent of the area involved.

Rockslides occurred on barren, south-facing slopes. Nearly all of these slides involved fractured bedrock in and adjacent to fault zones. Rockslides had steep head scarps exposing faulted bedrock. Blocks of limestone covered the upper parts of most rockslides; fine-grained material is abundant in the lower parts of the slides.

Landslides in surficial deposits differed from each other in size, shape, and thickness, but were similar in structure. Landslide areas ranged from 0.1 to 28 hectares, and shapes were long and narrow, short and wide, equidimensional, or irregular; the slides occurred on slopes of between $11^{\circ}$ and $30^{\circ}$ and were as much as 25 meters thick. Transverse cracks and head scarps, most from 1 to 3 meters high, defined the proximal boundaries of the landslides. Long, straight, strikeslip faults; zones of en echelon cracks; and longitudinal ridges defined the lateral boundaries. Steep toes, from 1 to 10 meters high, defined the distal boundaries. Cracks,

Manuscript approved for publication November 30, 1988. 80225.

${ }^{1}$ U.S. Geological Survey, Box 25046, MS 966, Denver, CO transverse normal faults, and transverse grabens formed on the surfaces of the landslides.

Debris flows affected about 26 hectares (1 hectare equals 2.47 acres), or about 0.8 percent of the study area. The flows were mobilized from layers of regolith $0.5-1.0$ meter thick on steep $\left(25-34^{\circ}\right)$ south- and west-facing slopes. The deposits and scars were 60-600 meters long, and $10-50$ meters wide, and the deposits were typically less than 3 meters thick.

\section{INTRODUCTION}

Landslides, debris flows, and floods ravaged parts of central Utah during 1983 and 1984 (Anderson and others, 1984). The Thistle landslide (1983) dammed Spanish Fork Canyon, and the resulting lake flooded the town of Thistle (fig. C1) and threatened communities downstream. Construction of outlet works and relocation of a highway and a railway at Thistle were costly (Duncan and others, 1986, p. 1). Two people were killed and houses were destroyed by debris flows at the town of Clear Creek, Utah, in May 1984. Facilities of the U.S. Forest Service were destroyed and roads, aqueducts, and power lines serving towns in the Sanpete Valley were damaged by landslides and debris flows in canyons on the west side of the Wasatch Plateau.

This chapter focuses on landslides, including rockslides, and debris flows that occurred in Ephraim Canyon, on the west side of the Wasatch Plateau, in central Utah, during 1983-1986 (fig. C1). The landslides and debris flows are studied in relation to the geology of Ephraim Canyon, which is similar to the geology of other canyons on the west side of the plateau. This chapter also contains background information relevant to detailed investigations of the Aspen Grove landslide in Ephraim Canyon.

Relations between landslides and debris flows that occurred from 1983 to 1986 and the bedrock and surficial 


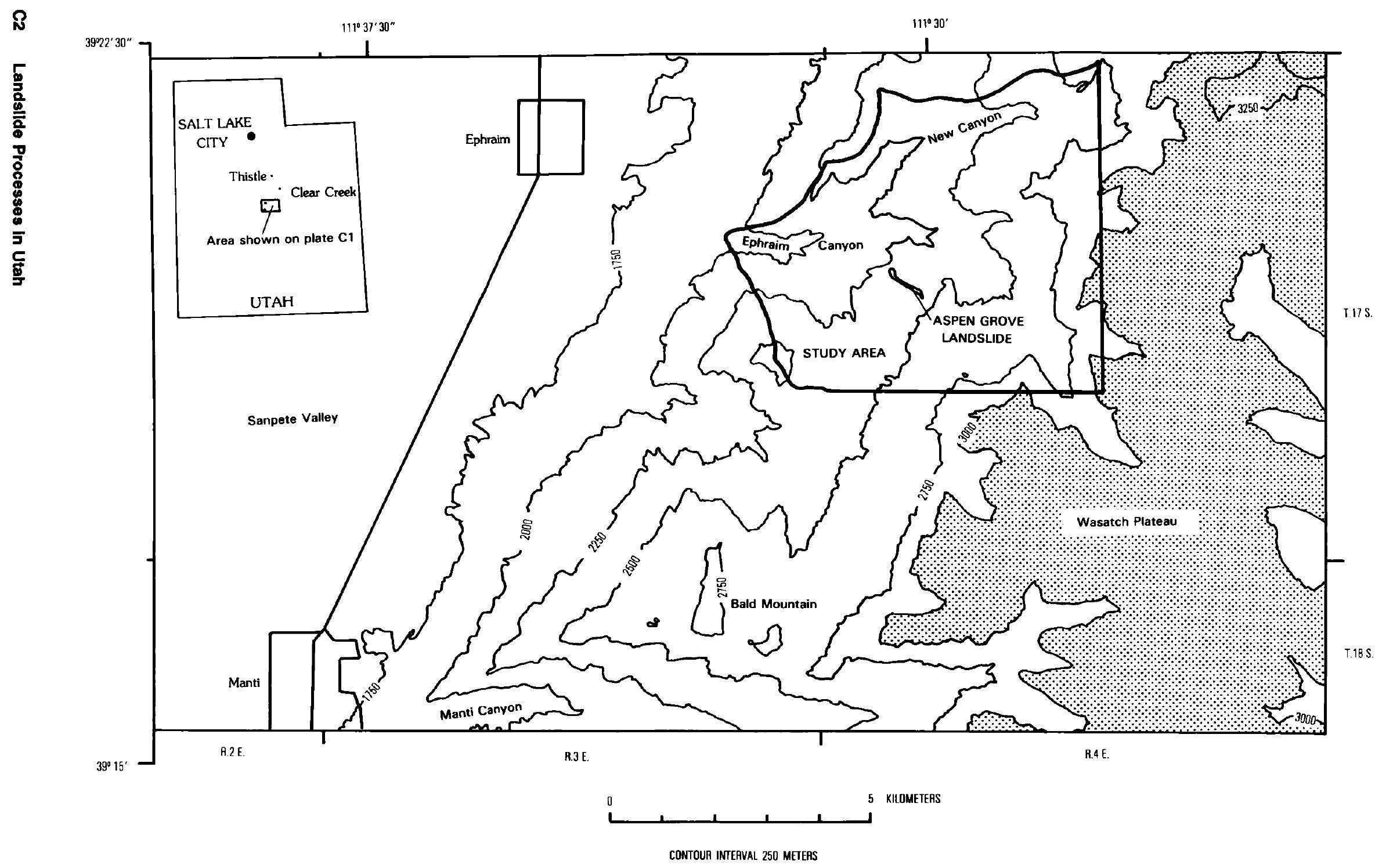

Figure C1. Map showing location of the study area. 
geology of Ephraim Canyon are shown on plate C1. The outlines of landslides and debris flows that had been active in 1983 and 1984 were transferred from aerial photographs taken on June 16,1984, directly to the base map, by means of a stereoplotter. Contacts between other geologic map units (including landslides that occurred in 1985 and 1986) were mapped in the field. Units older than the landslides and debris flows of 1983 were mapped in less detail and less accurately than the landslides of 1983 and 1984, because the contacts between older deposits are generally poorly expressed and faults in the bedrock are well exposed at only a few locations.

The mouth of Ephraim Canyon is at about 1,850 m elevation and is about $3 \mathrm{~km}$ southeast of the town of Ephraim (fig. C1). The canyon is about $5 \mathrm{~km}$ long and heads in the Wasatch Plateau, which is a slightly dissected, nearly horizontal surface between 3,050 and $3,200 \mathrm{~m}$ in altitude.

Much of the geomorphic expression of Ephraim Canyon can be related to geologic structure. Slopes that are subparallel to the dip direction generally are northwest- and west-facing slopes, and tend to be flatter than slopes that cut across bedding. Slopes that cut across bedding generally are east- and south-facing. Hogbacks (fig. C1) that stand at either side of the canyon mouth are held up by westward-dipping beds of the Wasatch monocline (Spieker, 1949). The steep, east-facing sides of the hogbacks are fault-line scarps. North-trending fault-line scarps form steps on the broad, blunt tops of canyon walls. An escarpment (extending through sections 9, 16, 21, and 29, T. 17 S., R. 4 E., pl. C1), $300 \mathrm{~m}$ high and west facing, along the west edge of the plateau, is probably a fault-line scarp.

\section{ACKNOWLEDGMENTS}

Ben Black (Manti District Ranger, USFS, Ephraim, Utah) and Gary Jorgenson (USFS, Ephraim, Utah) shared observations and helped solve various logistical problems. Roger Johnson (Ephraim, Utah) shared observations about some of the landslides described in this paper. Arvid Johnson (Purdue University, West Lafayette, Indiana) made several helpful suggestions about presentation of the data. We express our sincere appreciation to all these people.

\section{GEOLOGY OF EPHRAIM CANYON}

\section{Bedrock Geology}

The bedrock exposed in Ephraim Canyon consists of bedded sedimentary rocks that are divided into three formations (Spieker, 1946; Bonar, 1948; Witkind and others, 1982). Lowest, stratigraphically, is the Upper Cretaceous and Paleocene North Horn Formation, an orange to buff unit (fig. C2) that consists mostly of cemented sandstones interbedded with variegated shales. Conformably overlying the North Horn Formation is the Paleocene and Eocene Flagstaff Limestone, a white to buff unit about $275 \mathrm{~m}$ thick (fig. C2) that consists of limestone interbedded with gray, green, and black shales (LaRocque, 1960; Stanley and Collinson, 1979). The Eocene Colton Formation overlies and intertongues with the Flagstaff Limestone (Zawiskie and others, 1982). Beds of the Colton Formation that are exposed in Ephraim Canyon consist of lenticular sandstone, limestone, and reddish-brown shale.

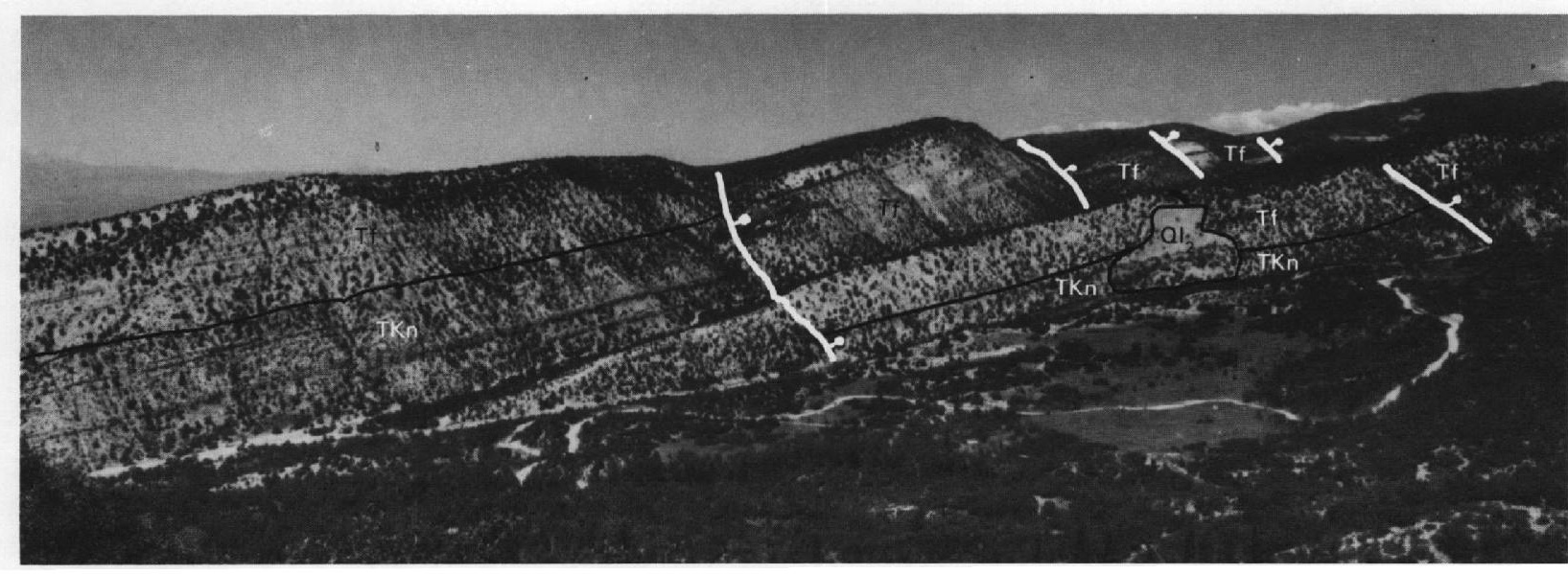

Figure C2. Photograph showing exposures of the North Horn Formation (TKn) and the Flagstaff Limestone (Tf) on the north side of Ephraim Canyon (looking north from Bald Mountain, fig. C1). A rockslide $\left(\mathrm{Ql}_{2}\right)$ on the north side of Ephraim Creek is shown near the right-hand edge of the photograph. Ball and bar on downthrown side of fault. 
Steep, north-trending faults (pl. C1) break the rocks of the canyon into a series of elongate blocks. The blocks have been tilted so that the bedding within them dips toward the west (Bonar, 1948; Spieker, 1949). The dips of beds within the blocks increase westward from horizontal at the rim of the Wasatch Plateau (at the eastern edge of the area) to $25-40^{\circ}$ in the hogbacks that flank the mouth of the canyon (pl. C1). Stratigraphic offsets on several faults range from $100 \mathrm{~m}$ to $360 \mathrm{~m}$ (pl. C1). Displacement across some of the faults and tilting of some of the blocks are large enough that locally the North Horn Formation is topographically higher than the Flagstaff Limestone.

Bedrock crops out on steep slopes and in cliffs. In the map area, bedrock is exposed primarily in southfacing slopes of New Canyon and Cottonwood Creek, in cliffs along the edge of the plateau at White Ledge and the Great Basin Experiment Station, in the area between Maple Creek and Cottonwood Creek, and in the rims of the hogbacks (pl. C1; fig. C2).

Much of the area mapped as bedrock is covered by a thin layer of residual material (residuum) that has formed in place as a result of mechanical and chemical weathering. The residuum is not considered to be masswasting material. Residuum weathered from the North Horn Formation consists of clasts of yellow or gray sandstone in a matrix of orange or tan sandy clay. Residuum derived from the Flagstaff Limestone is characterized by boulder-, cobble-, and pebble-sized clasts of white or light-gray limestone in a matrix of white, gray, or brown clay. White limy sandstone, silicified limestone, and chert are locally abundant in residuum of the Flagstaff Limestone.

\section{Surficial Geology}

In addition to deposits of landslides and debris flows that occurred between 1983 and 1986, four kinds of surficial deposits are recognized in the area: alluvium; pre-1983 debris-flow deposits; pre-1983 landslide deposits; and slope deposits consisting of undifferentiated surficial materials that include colluvium, slope wash and, locally, alluvium, residuum, and outcrops of bedrock that were too small to map separately. Some deposits that we suspected were pre-1983 landslides or debris flows were also mapped as slope deposits because the surface expression of individual slides or flows was too subtle to identify. In the text, these undifferentiated materials are referred to collectively as slope deposits and they correspond to the map unit Qc (pl. C1). Thus, the map shows three types of pre-1983 mass-wasting deposits: pre-1983 landslide deposits, pre-1983 debrisflow deposits, and slope deposits.

Pre-1983 landslide deposits.-Pre-1983 landslide deposits consist of unsorted, unstratified mixtures of limestone and sandstone boulders, cobbles, and pebbles in a sandy clay matrix. These deposits might be as much as $50 \mathrm{~m}$ thick. Topsoil as much as several decimeters thick has developed on most pre-1983 landslides.

Pre-1983 landslide deposits cover about one quarter of the study area. Several deposits are on northand west-facing slopes in New Canyon, and a large deposit occupies the head of New Canyon. Other large deposits are between White Ledge and the Great Basin Experiment Station, and in the area south of Maple Creek (pl. C1). Individual deposits range in area from 1 to 240 hectares (ha); they range in thickness from a few meters to perhaps $50 \mathrm{~m}$. Their surfaces generally slope $7-13^{\circ}$; however, the surfaces of a few pre-1983 landslides slope as much as $26^{\circ}$ and local slopes on some slides are as great as $33^{\circ}$. Hummocks, closed depressions, benches, arcuate troughs, lateral ridges, and lobate toes are common on the surfaces of these deposits. Some deposits are elongate, others are wide at the head and narrow gradually toward the toe, and still others are roughly equidimensional.

Several of the larger landslides consisted of material from the North Horn Formation, and occurred at the base of steep cliffs along the rim of the plateau. An example of a pre-1983 landslide deposit of this type, is the deposit mapped between the Great Basin Experiment Station and Cottonwood Creek (sections 16, 17, 20, and 21, T. 17 S., R. 4 E.). The southern end of the deposit represents the head of the landslide; a steep cliff exposing horizontally layered bedrock towers above the southern end of the deposit. The outline of the head is roughly arcuate. A curving, transverse ridge about $300 \mathrm{~m}$ north of the base of the cliff is a distinctive topographic feature on the surface of the deposit. (We have observed similar ridges at the heads of other large landslides in the plateau.) Downslope from the head area, the surface of the deposit slopes about $8^{\circ}$ toward the north-northwest, and the deposit narrows gradually. Closed depressions, which were expressed on the June 1984 aerial photographs as ponds, are common between the head and Cottonwood Creek. At Cottonwood Creek, the deposit turns to the west and narrows. Along both sides of Cottonwood Creek, remnants of the deposit form a terrace that slopes downstream and can be traced to the vicinity of Cottonwood Spring (NE1/4 sec. 18, T. 17 S., R. 4 E.).

Pre-1983 debris-flow deposits. -Deposits of pre1983 debris flows were recognized on the basis of their morphology and recognizable deposits are of limited extent. They consist of angular cobbles and boulders of limestone and sandstone in a poorly sorted matrix of sandy clay. The debris-flow deposits are probably less than $2 \mathrm{~m}$ thick. Thin soil is developed on the surface of the debris-flow deposits. 
Individual debris-flow deposits are difficult to recognize in the area. However, on a south-facing slope in New Canyon (SW1/4 sec. 7, T. 17 S., R. 4 E.) and on a north-facing slope near Bluebell Flat (sec. 21, T. 17 S., R. $4 \mathrm{E}$.), it is possible to distinguish single pre-1983 debrisflow deposits. The New Canyon deposit covers 2.5 ha, and the Bluebell Flat deposit covers 4.0 ha. The deposits are elongate, have bulbous terminations, and lie in and adjacent to channels that slope from $17^{\circ}$ to $26^{\circ}$. The surfaces of the deposits are littered with angular rock fragments and are partly covered with vegetation.

Slope Deposits.-Slope deposits consist of unsorted, unstratified, or poorly stratified mixtures of limestone or sandstone boulders, cobbles, pebbles, sand, silt, and clay. Most slope deposits are probably less than $5 \mathrm{~m}$ thick, but locally might be as much as $25 \mathrm{~m}$ thick. The deposits occur on slopes as steep as $27^{\circ}$. Slope deposits typically have topsoil that is several decimeters thick and dark brown.

Slope deposits are particularly common on northand west-facing slopes that are subparallel to dip of the bedrock (pl. C1). Slope deposits are on the south side of New Canyon, on Dusterburgs Hill, and in the area between Maple Creek and Cottonwood Creek. Steep slopes along the west edge of the Wasatch Plateau are covered by deposits of colluvium from 0.5 to $1.0 \mathrm{~m}$ thick. The surfaces of slope deposits are typically smooth or slightly rolling; however, hummocks, ridges, or closed depressions occur at isolated locations.

Alluvium. - Alluvium is limited to channels of Ephraim Creek and its tributaries, Maple Creek, Cottonwood Creek, and New Creek. It consists of locally derived gravel, laminated sands or silts, and clay. Alluvium occurring at levels above the active stream channels (terrace deposits) is found along the banks of Ephraim Creek and New Creek.

\section{LANDSLIDES OF 1983-1986}

Many spectacular landslides occurred in 1983 and 1984 and movement in some of the landslides was renewed during 1984, 1985, and 1986. In general, the occurence of landslides in 1983 and 1984 was related to infiltration of snow meltwater and coincided with rapid melting of the snowpack. Large landslides consisting of old landslide debris or other surficial materials typically began to move before the snowpack was gone and movement fractured the snow into intricate patterns. During snowmelt, bedrock became saturated in places, failed, and moved downslope as rockslides.

Landslide movement that began in early spring of 1983 typically ended during July or August 1983, and apparently did not begin again until the spring of 1984 . This pattern of landslide activity, movement during spring and early summer followed by dormancy during fall and winter, has been documented for reactivation of the large Manti landslide several kilometers south of the study area in Manti Canyon (Fleming and others, in press).

The landslides are distributed throughout the area and their deposits cover about 166 ha, or about 4.7 percent of the study area. About 94 ha (57 percent) were reactivations of old (pre-1983) landslide debris, 39 ha occurred in slope deposits, and 33 ha (20 percent) occurred in bedrock.

Shapes, sizes, and slopes of the landslides varied widely. Areas ranged from about 0.1 to $28 \mathrm{ha}$, and thicknesses were as much as $25 \mathrm{~m}$. The average surface slopes of individual landslides ranged from about $11^{\circ}$ to $30^{\circ}$. Some landslides, such as the Aspen Grove landslide, were long and narrow. Others, such as those along the banks of Cottonwood Creek, were short and wide. Many others were equidimensional, and a few had irregular shapes.

In general, the heads were flat or gently sloping, the bodies of the landslides sloped more or less uniformly, and the toes were relatively steep. In order to illustrate the settings and general features of the landslides, representative examples are described.

\section{The Aspen Grove Landslide}

The Aspen Grove landslide occurred in pre-1983 landslide debris on a northwest-facing slope between Cottonwood Creek and Maple Creek (SW1/4 sec. 17 and SE1/4 sec. 18, pl. C1). Most of the pre-1983 debris at the site was mobilized by the slide, which is surrounded by other slope deposits and bedrock (pl. C1). The landslide is about $1 \mathrm{~km}$ long, and its width ranges from 30 to $100 \mathrm{~m}$. Its thickness is $6 \mathrm{~m}$ near the proximal end and probably ranges from 4 to $15 \mathrm{~m}$, with an average thickness of $6 \mathrm{~m}$. The volume of the landslide is $3.6 \times 10^{5} \mathrm{~m}^{3}$. The average slope of the landslide surface is $12^{\circ}$.

The landslide surface is covered with trees, grass, and shrubs, most of which have survived several meters of displacement. Gaping cracks define the head, welldeveloped shear zones mark the lateral boundaries, and small toes separated by apparently undeformed ground define the presumed distal boundary of the landslide. Cracks, thrusts, and other deformational features occurred on the surface of the landslide. Longitudinal ridges at the lateral boundaries and a large lobate toe about $300 \mathrm{~m}$ upslope from the present distal boundary of the landslide are remnants from a previous episode of movement. Much of the landslide is slightly higher than the neighboring ground:

The landslide debris contains large sandstone boulders derived from the North Horn Formation. Similar boulders are present on the slopes adjacent to the landslide, but outcrops near the landslide are of Flagstaff 
Limestone. The North Horn Formation crops out a few hundred meters upslope from the head of the Aspen Grove landslide, thus the debris has moved hundreds of meters downslope from its source.

The landslide became active in May 1983 and moved a few millimeters to a few centimeters per day until it stopped moving in mid-July 1983. Movement started again in April or May 1984 and continued until August 1984. Similar patterns of movement were repeated in 1985 and 1986. Although some of the landslide debris has been broken or remolded, the material has flowed very little. During 1984 and 1985 the landslide damaged the road (Utah highway 29) in two places, making it impassable to vehicles until repaired.

Meltwater infiltrating from the surface was probably the main source of water responsible for reactivating the Aspen Grove landslide. However, there was probably some contribution from subsurface water, because springs were observed near the head of the landslide and near its toe, downslope from the aqueduct (pl. C1).

\section{The Dusterburgs Hill Landslide}

The Dusterburgs Hill landslide is another example of a long, narrow, slope failure that originated in pre1983 landslide and slope deposits. It is located on Dusterburgs Hill, near the middle of sec. 8 (pl. C1). The landslide is about $1 \mathrm{~km}$ long, and its width ranges between 35 and $120 \mathrm{~m}$. The landslide is probably between 4 and $8 \mathrm{~m}$ thick, with an average thickness of perhaps 6 $\mathrm{m}$. Its volume is about $3.8 \times 10^{5} \mathrm{~m}^{3}$. The upper half of the landslide slopes toward the northwest; about midway between the head and toe, the landslide turns abruptly toward the west (fig. C3). The average slope of the surface is about $13^{\circ}$. The dominant mode of movement was sliding; only a small amount of the material flowed.

The geometry of the Dusterburgs Hill landslide differs in some details from that of the Aspen Grove landslide. An arcuate head scarp, from 2 to $3 \mathrm{~m}$ high, defines the proximal boundary of the landslide. The surface of the upper half of the landslide is slightly lower than neighboring ground. Well-developed shear zones mark the lateral boundaries, and a steep toe, from 1.5 to $2.0 \mathrm{~m}$ high, marks the distal boundary. The surface of the landslide was strongly deformed and is broken by many cracks. Most trees and shrubs growing on the landslide were uprooted by its movement (fig. C3).

The sharp bend in the landslide is a unique feature. Most landslide debris slid out of the bend, leaving a bowl-like depression 3-4 m deep (fig. C3). Red shale, probably of the Colton Formation, is exposed in the bottom of the depression. During the summer of 1985 , two small springs were observed near the margins of the depression.

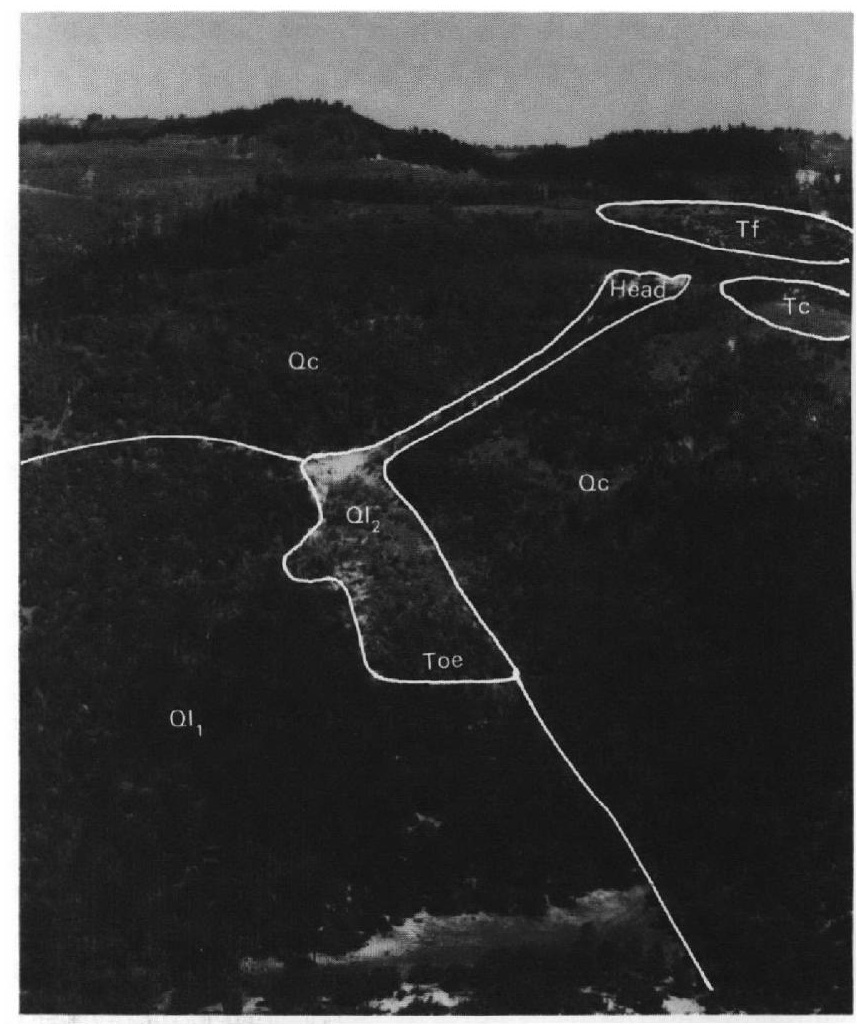

Figure C3. Photograph of the Dusterburgs Hill landslide, looking east from the northwest rim of New Canyon. $\mathrm{Ql}_{2}$, Dusterburgs Hill landslide; $\mathrm{Ql}_{1}$, pre-1983 landslide deposit; Qc, slope deposits; Tf, Flagstaff Limestone; Tc, Colton Formation. All contacts approximately located.

Unlike debris in the Aspen Grove landslide, the debris in the Dusterburgs Hill landslide appears to have been derived from bedrock in the immediate vicinity of the landslide. Boulders and cobbles in the landslide and on the adjacent slopes are limestone and limy sandstone derived from the Flagstaff Limestone and the Colton Formation, both of which underlie the landslide (see plate $\mathrm{C} 1$ ).

The landslide probably was active only during 1983 and 1984. Dead trees and shrubs on the surface of the landslide already looked dry and brown in June 1984. Features on the surface of the landslide were displaced as much as $20 \mathrm{~m}$.

\section{The Majors Flat Landslide}

The Majors Flat landslide is a relatively large, irregularly shaped failure in colluvium overlying bedrock (sec. 13, T. 17 S., R. 3 E., and sec. 18, T. 17 S., R. 4 E.; pl. C1). The landslide is $590 \mathrm{~m}$ long; its upper part is 320 $\mathrm{m}$ wide, and its lower part is $190 \mathrm{~m}$ wide. Its thickness ranges from 1 to as much as $20 \mathrm{~m}$. Assuming an average thickness of $10 \mathrm{~m}$, its volume is approximately $9.6 \times 10^{6}$ 
$\mathrm{m}^{3}$. The average slope of the landslide surface is from $10^{\circ}$ to $11^{\circ}$ (fig. $\mathrm{C} 4 A$ ). In plan view, the landslide is shaped about like Africa, with the head of the landslide corresponding to the north coast of Africa, and the toe of the landslide to the Cape of Good Hope (figs. C4B, $\mathrm{C} 4 \mathrm{C})$.

Deformation due to movement occurred mainly around the edges of the landslide; the central part is relatively uncracked and undeformed (fig. $\mathrm{C} 4 C$ ). The head scarp of the landslide is rough and irregular, and stands from 1 to $3 \mathrm{~m}$ high. A region immediately below the head scarp, 30-60 $\mathrm{m}$ long and extending the full width of the landslide, is broken into long blocks, from 1 to $4 \mathrm{~m}$ wide, that are bounded by transverse cracks and scarps. En echelon cracks and segmented faults (fig. $\mathrm{C} 4 \mathrm{C}$ ) define the flanks of the landslide. A slightly sinuous toe, 1-2 m high, connects the right flank of the wide upper half of the landslide to the right flank of the narrower, lower half of the landslide (fig. $\mathrm{C} 4 C$ ). Imbricated thrust sheets occur in the foot of the landslide; the edges of the thrust sheets are defined by steep, sinuous ridges from 0.5 to 1.5 m high.

Debris in the landslide consists of boulder-, cobble, and pebble-size clasts of limestone and sandstone in a sandy clay matrix. The debris is derived from the Flagstaff Limestone, which underlies the steep slope along the east margin of the landslide, and the North Horn Formation, which underlies the body of the landslide.

The landslide started moving during the spring of 1983 and was active for several weeks until mid-summer 1983. The landslide started moving again in the spring of 1984, when it broke a water line that supplied the city of Ephraim and destroyed some buildings belonging to the U.S. Forest Service. Measurements made by Roger Johnson (oral commun., 1984) showed that the landslide was moving a few centimeters per day in May 1984. The landslide gradually slowed to a stop sometime in June or July 1984.

Seeps observed at several places on the surface of the landslide indicate that subsurface water played a role in sustaining movement. Several seeps occurred along the trace of the pipeline (aqueduct), suggesting that there were leaks in the pipe. Other seeps occurred in the toe that could not be directly attributed to any man-made source of water. Surface water from a spring east of the landslide spilled onto the surface and soaked into the ground at the head of the landslide. It seems probable that infiltrating meltwater and spring water triggered the landslide, and that water from the leaking pipe helped sustain the movement.

The Aspen Grove, Dusterburgs Hill, and Majors Flat landslides are typical of landslides in unconsolidated deposits in the study area, regardless of shape and size. The debris consists of a bouldery sandy clay; the landslides moved by translation at rates of a few millimeters to a few centimeters per day, tension cracks and scarps from 1 to $3 \mathrm{~m}$ high characterized the landslide heads, the lateral boundaries were well marked by shear zones, and the surfaces of the landslides were only slightly cracked and deformed.

\section{The Rockslide at Cottonwood Spring}

Many distinguishing features of bedrock landslides are illustrated by a rockslide in the fault zone upslope from Cottonwood Spring, SE1/4 sec. 7, T. 17 S., R. 4 E. (fig. C5). The rockslide is about $170 \mathrm{~m}$ long, its head is about $45 \mathrm{~m}$ wide, but the landslide tapers gradually so that the toe is about $5 \mathrm{~m}$ wide. The thickness ranges from 1 to $8 \mathrm{~m}$ and the average is about $4 \mathrm{~m}$. The volume of the landslide is approximately $1.8 \times 10^{4} \mathrm{~m}^{3}$. The slope of the ground surface, where the landslide occurred, was about $30^{\circ}$.

The head scarp exposes fractured limestone bedrock of the Cove Mountain Member of the Flagstaff Limestone. The head of the slide slopes a few degrees toward the south. It is covered with porous, white, limestone blocks. The body and toe of the landslide consist of an unsorted mixture of silty clay with angular fragments and blocks of limestone. Dead trees lying in various positions dot the surface of the slide (fig. C5).

Geometry of the landslide suggests that failure originated in the head. Because the head of the slide is the largest displaced mass, we speculate that water moved downward along cracks in the vicinity of the head and caused the jointed rock to fail first. Subsequently, loose material slid down the surface of the slope to form the thinner and narrower deposits near the toe.

The rockslide at Cottonwood Spring is typical of the rockslides on the north wall of New Canyon and the north wall of the canyon occupied by Cottonwood Creek (pl. C1). Thickly bedded, fractured, faulted limestone is exposed in the head scarps. The heads are wide relative to the bodies of the landslides. The distal ends or toes of some rockslides had a high proportion of fine-grained material and a lobate morphology.

Nearly all rockslides on the north walls of New Canyon and the canyon occupied by Cottonwood Creek occurred in fault zones (pl. C1). The head scarps of the rockslides expose beds of thick, jointed, and faulted limestone or sandstone. The faults and joints presumably weakened the rock and facilitated the movement of ground water. Wet spots were observed in fault gouge exposed in the head scarps of several of the bedrock landslides. A spring was observed on the right side of a large bedrock landslide located in New Canyon (SW1/4 sec. 5). Cottonwood Spring, which has been developed for water supply, flows from the same fault zone that is exposed in the head of the rockslide just described. 


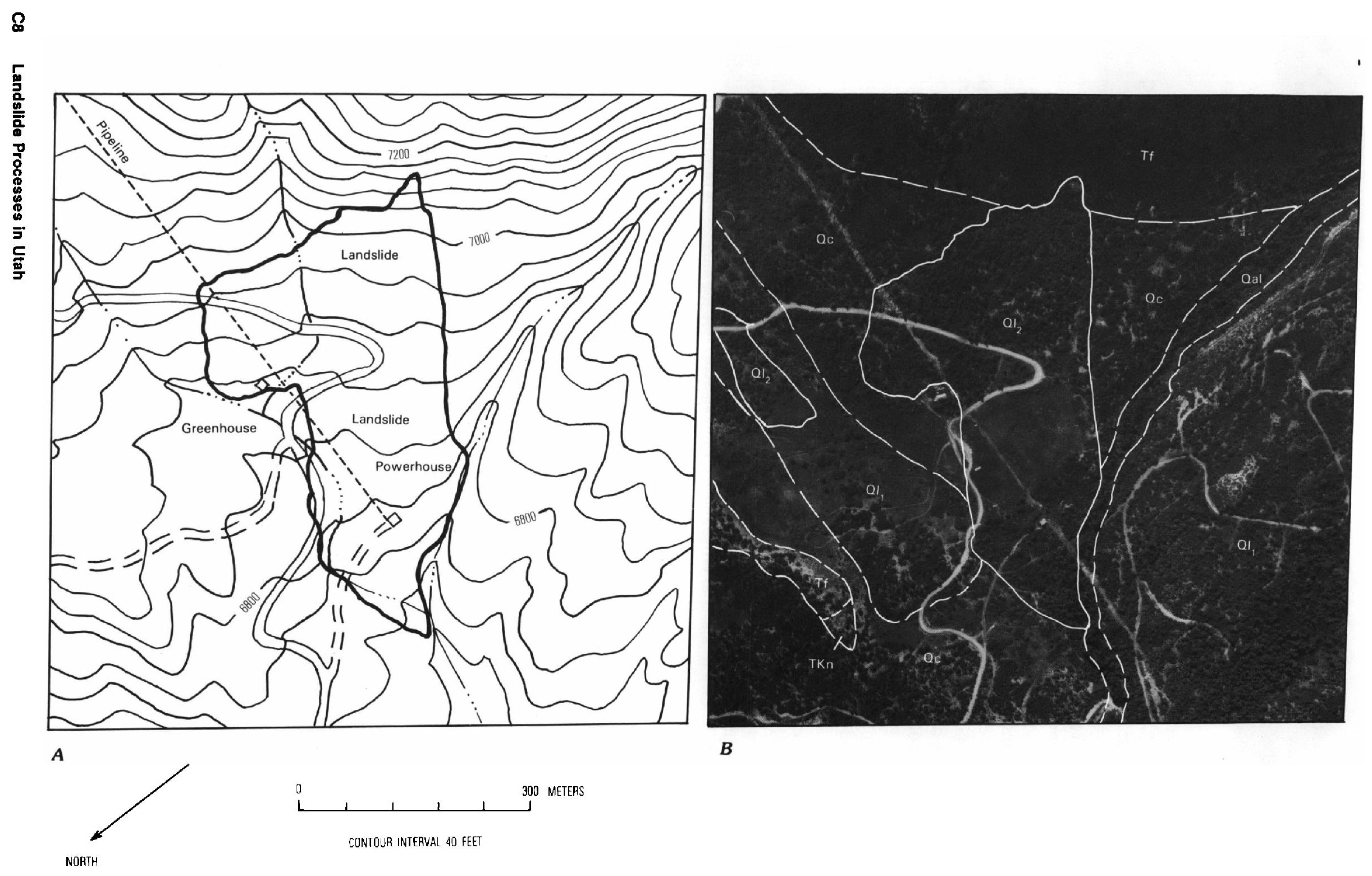




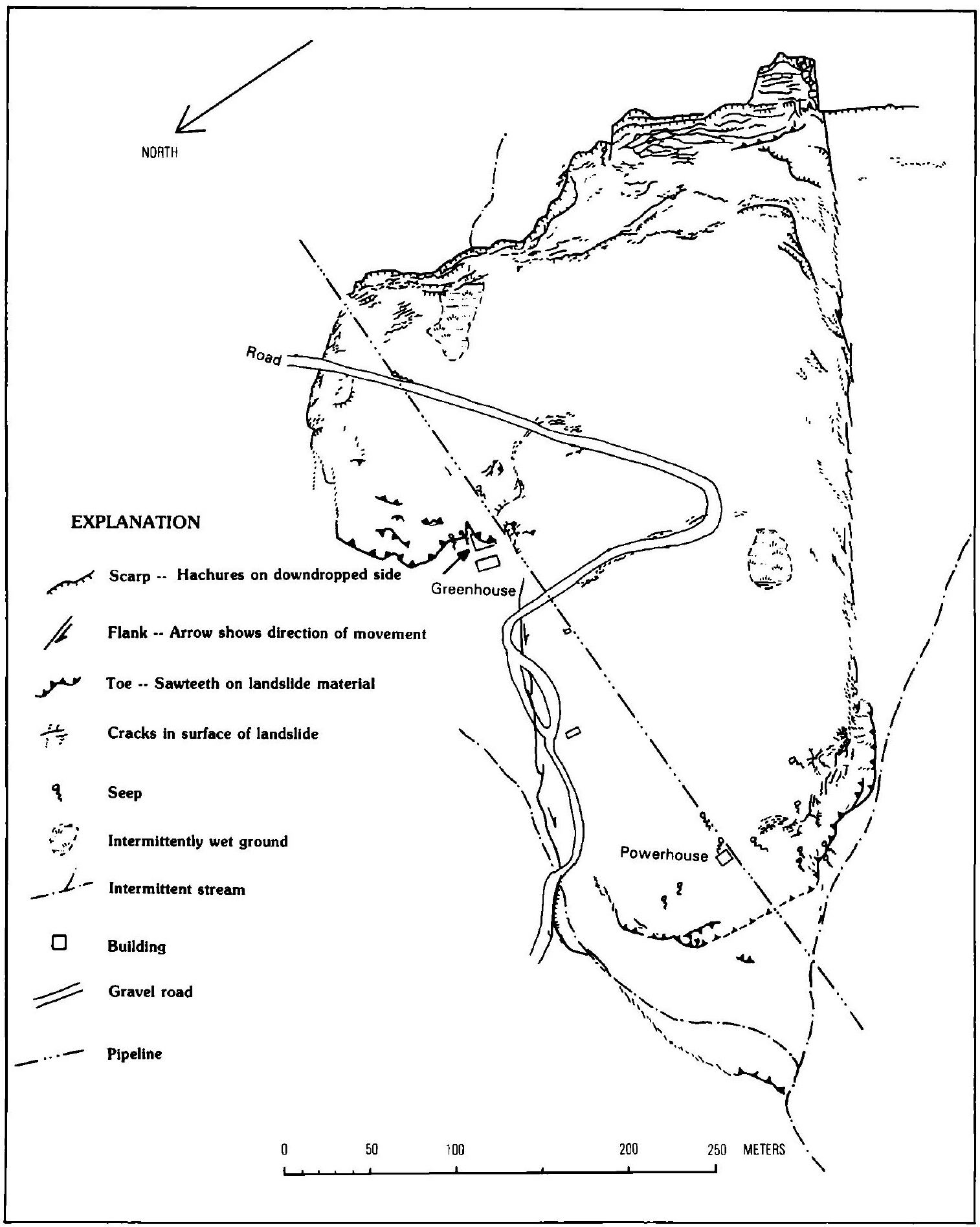

C

Figure C4 (above and facing page). Majors Flat landslide. $A$, Pre-landslide topographic map redrafted from Ephraim 71/2-minute quadrangle (USGS). $B$, vertical aerial photograph. Map units on photograph correspond to map units on geologic map (pl. C1). Dashed contacts, approximately located. $C$, map showing features at the surface of the landslide. 


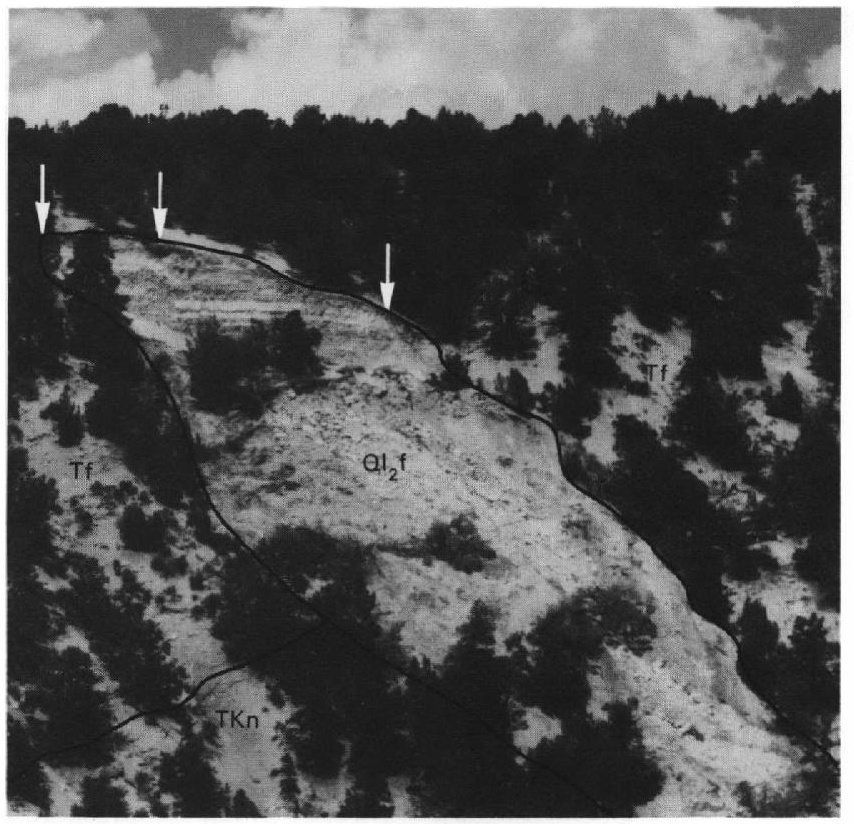

Figure C5. Photograph showing a rockslide near Cottonwood Spring. Faulted, thickly bedded limestone of the Flagstaff Limestone is exposed in the head scarp. Arrows indicate locations of three different faults. Tf, Flagstaff Limestone; TKn, North Horn Formation; $\mathrm{Ql}_{2} \mathrm{f}$, 1983-1986 rockslide.

\section{DEBRIS FLOWS OF 1983-1986}

In May 1983, surficial materials on slopes in Ephraim Canyon became water saturated, and in many places failed and moved downslope as debris flows. In general, the debris flows of 1983 coincided with rapid melting of the snowpack. In the Wasatch Plateau and other parts of Utah, debris flows were mobilized from parts of large pre-1983 landslides and from thin colluvium on steep hillslopes. Mobilization of colluvium seemed to coincide with the most rapid melting. After the snow line receded above any given elevation point, no new debris flows formed below that elevation. A few debris flows occurred during intense thunderstorms in 1984 and 1985. Two debris flows occurred during 1985, at places in Ephraim Canyon where water leaking from aqueducts had saturated colluvium on slopes.

Debris flows were active in the study area during the springs of $1983,1984,1985$, and 1986 . The debris flows occurred on slopes ranging from $13^{\circ}$ to $34^{\circ}$; many of them occurred on steep $\left(25-34^{\circ}\right)$, colluvium-covered slopes in the eastern part of the area. The remainder mobilized from landslide dcposits distributed throughout the area or from loose, weathered bedrock exposed on the north walls of New Canyon and the canyon occupied by Cottonwood Creek. The debris flows covered a total of 26 ha, or about 0.8 percent of the study area. The debris-flow scars and deposits appear as long, narrow strips and irregular blobs on the map. Most are between 10 and $50 \mathrm{~m}$ wide and from 60 to $600 \mathrm{~m}$ long. Typically, the scars are less than $1 \mathrm{~m}$ deep and the deposits are less than $3 \mathrm{~m}$ thick. The long, narrow debris flows were channelized; they flowed in preexisting swales or gullies. At several locations, neighboring debris flows coalesced to produce the irregular shapes shown on the map. Some of the debris flows were sheetlike and unchannelized, occurring on smooth, ungullied slopes.

Cobbles, large boulders, broken trees, and lightbrown mud covered the surfaces of the debris-flow deposits to a depth of from a few centimeters to a few decimeters. The smooth, light-brown mud contrasted with the dark brown, vegetated topsoil on adjacent ground. The boulders and broken trees were arranged in heaps so that parts of the deposits had an irregular surface topography.

The debris flow that occurred in 1986 at Cottonwood Spring (fig. C6) was notably different from debris flows that occurred at other localities in Ephraim Canyon during 1983. The 1986 debris flow began as a landslide in bedrock on a dip slope. We observed a few widely spaced cracks on the upper part of the dip slope in 1984 or 1985, but a slope failure was unexpected because many of the landslides that had been active in 1983 or

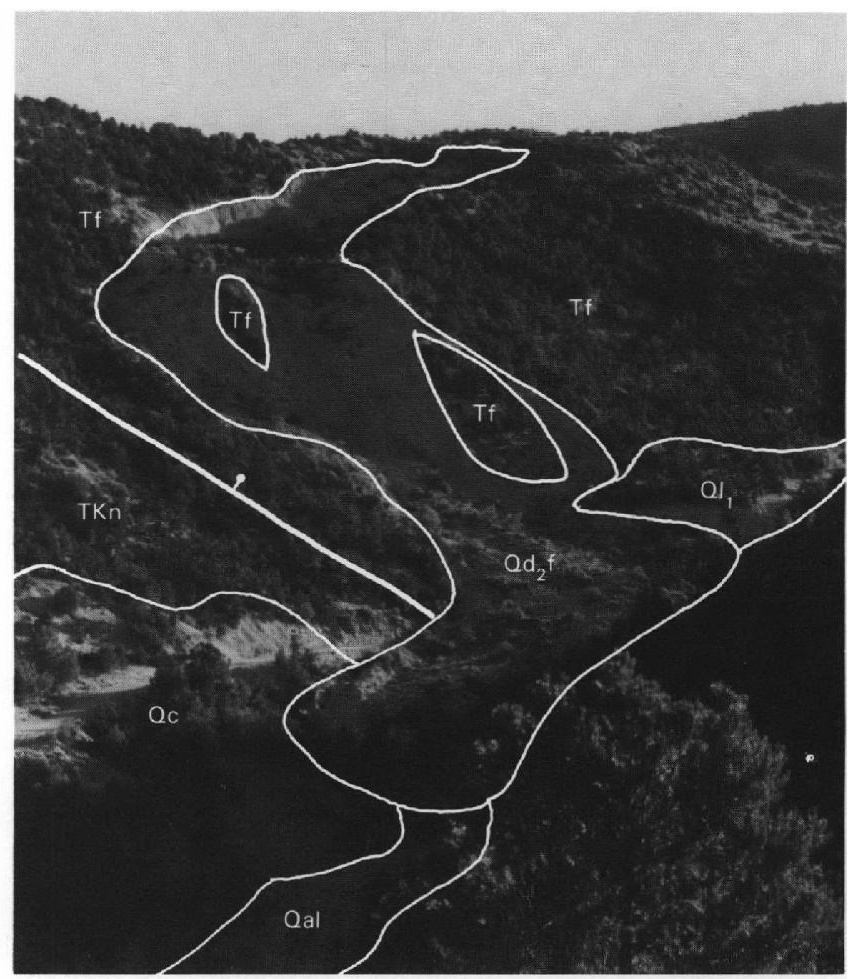

Figure C6. Photograph showing the Cottonwood Spring debris flow of 1986. Tf, Flagstaff Limestone; TKn, North Horn Formation; Qc, colluvium and slope wash; $\mathrm{Ql}_{1}$, Pre-1983 landslide deposit; Qal, alluvium; $\mathrm{Qd}_{2} \mathbf{f}$, debris flow of 1986. All contacts approximately located. (Photograph by Arvid Johnson). 
1984 had stopped by 1985 . However, sliding and debrisflow movement started on about April 15, 1986 and continued for several days. Material slid down the dip slope, gradually being remolded until it began flowing, and then cascaded over steep slopes toward Ephraim Creek. In the bottom of the canyon, the flow moved a few meters per hour (Roger Johnson, oral commun., 1986). The flow partially dammed and diverted the creek, and covered an intake structure for a power plant at the mouth of Ephraim Canyon.

The Cottonwood Spring debris flow differed from typical debris flows in Ephraim Canyon in that it developed slowly for one or two years before it failed abruptly in 1986. It moved more slowly than other debris flows, was active for several days, and was mobilized from a layer of weathered bedrock several meters thick rather than from colluvium.

\section{DISCUSSION AND CONCLUSION}

Much of Ephraim Canyon is covered by pre-1983 landslide debris, including parts of areas labeled slope deposits (Qc) on the map. Many of the pre-1983 landslide masses are much larger than the landslides of 1983-86. The abundance of large landslide deposits in the area, that did not slide in 1983, indicates that the 1983 event is not unique and may have been overshadowed by past events.

About 80 percent of the area involved in recent landslides was underlain by old landslide deposits and slope deposits, 57 percent in pre-1983 landslide deposits plus 23 percent in slope deposits. The colluvium and pre-1983 landslide deposits are derived from similar parent materials, have similar textures, and together cover perhaps 70 to 80 percent of Ephraim Canyon. Because the deposits are so widespread, we cannot reach any conclusions about the stability of these deposits compared to bedrock and residuum.

Nearly all rockslides during 1983-84 occurred where fault zones intersect barren, south-facing slopes in New Canyon and Cottonwood Canyon. Rockslides constituted about 20 percent of the area of recent landslides.

Ten or eleven rockslides that occurred on the south-facing slopes of Cottonwood Canyon and New Canyon constitute the majority of first-time failures. A few small landslides and debris flows that resulted from failure of loose, weathered bedrock on the south-facing slopes of the canyon occupied by Cottonwood Creek and New Canyon constitute the remainder of the first-time failures. ${ }^{2}$

\footnotetext{
${ }^{2}$ First-time failures are indicated on the map (pl. C1).
}

The locations of only some of the first-time failures might have been predicted. It was noted that rockslides occurred in fault zones on south-facing slopes.

The debris flow of 1986, at Cottonwood Spring, was less predictable than the rockslides. During 1984 or 1985, a few cracks were noticed on the dip slope where the flow originated, but the cracks did not obviously outline a landslide. Many other landslides had dried out and stopped moving in 1983 or 1984 . The snowfall during 1985 and 1986 was less than in 1983 and 1984, and the cracks were on a south-facing slope. South-facing slopes in the area are dry, especially compared to north-facing slopes. Although we were initially surprised when the material on the dip slope failed and started flowing during the spring thaw in April 1986, in retrospect, the developing cracks warned of impending failure.

Our significant findings can be summarized as follows. Landslide and debris-flow deposits cover at least 60 percent of the study area, and many of the pre-1983 landslides were much larger than any of the landslides that occurred from 1983 to 1986 . Fractured bedrock occurring in fault zones of Ephraim Canyon is likely to fail and form rockslides. Some materials in the study area fail progressively, but cracks may form at the surface as much as two years before catastrophic failure occurs.

\section{REFERENCES CITED}

Anderson, L.R., Keaton, J.R., Saarinen, T.F., and Wells, W.G., II, 1984, The Utah landslides, debris flows, and floods of May and June 1983: National Research Council, National Academy Press, Washington, D.C., 96 p.

Bonar, C.M., 1948, Geology of Ephraim area, Utah: Columbus, Ohio, Ohio State University M.S. thesis, 124 p.

Duncan, J.M., Fleming, R.W., and Patton, F.D., 1986, Report of the Thistle Slide Committee to State of Utah Department of Natural Resources Division of Water Rights: U.S. Geological Survey Open-File Report 86-505, $95 \mathrm{p}$.

Fleming, R.W., Johnson, R.B., and Schuster, R.L., in press, The reactivation of the Manti landslide, Utah, in Fleming and others, The Manti, Utah, Landslide: U.S. Geological Survey Professional Paper 1311.

LaRocque, A., 1960, Molluscan faunas of the Flagstaff Formation of central Utah: Geological Society of America Memoir 78, 100 p.

Spieker, E.M., 1946, Late Mesozoic and early Cenozoic history of central Utah: U.S. Geological Survey Professional Paper 205D, p. 117-161.

Spieker, E.M., 1949, The transition between the Colorado plateaus and the Great Basin in central Utah: Utah Geological Society Guidebook 4, 106 p.

Stanley, K.O., and Collinson, J.W., 1979, Depositional history of Paleocene-lower Eocene Flagstaff Limestone and coeval rocks, central Utah: American Association of Petroleum Geologists Bulletin, v. 63, no. 3, p. 311-323. 
Witkind, I.J., Weiss, M.P., and Brown, T.L., 1987, Geologic map of the Manti 30' $\times 60^{\prime}$ quadrangle, Carbon, Emery, Juab, Sanpete, and Sevier Counties, Utah: U.S. Geological Survey Miscellaneous Investigations Map I1631, scale 1:100,000.
Zawiskie, J., Chapman, D., and Alley, R., 1982, Depositional history of the Paleocene-Eocene Colton Formation, north-central Utah, in Nielson, D.L., ed., Overthrust Belt of Utah: Utah Geological Association Publication 10, p. 273-284.

C12 Landslide Processes In Utah 


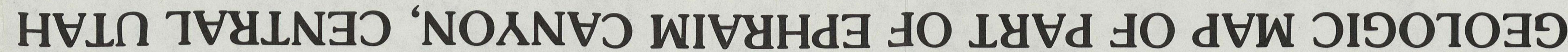



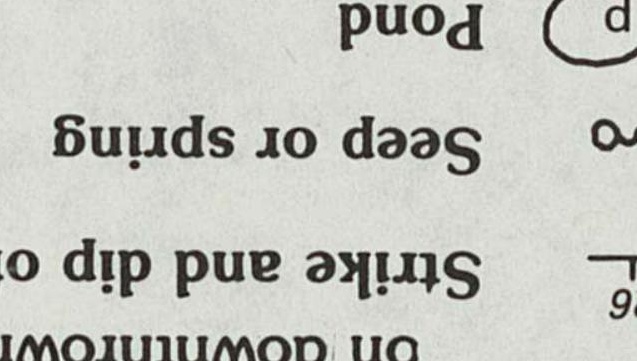

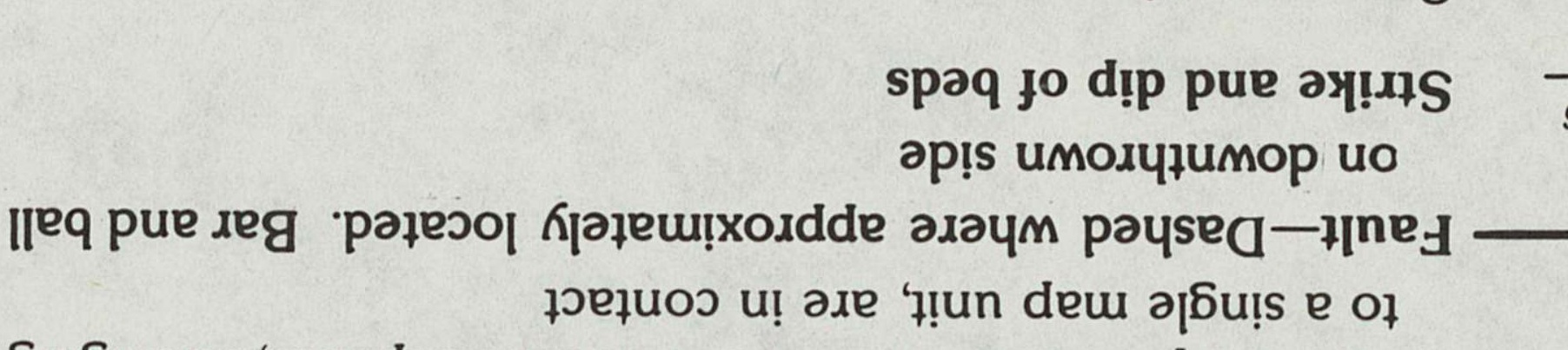

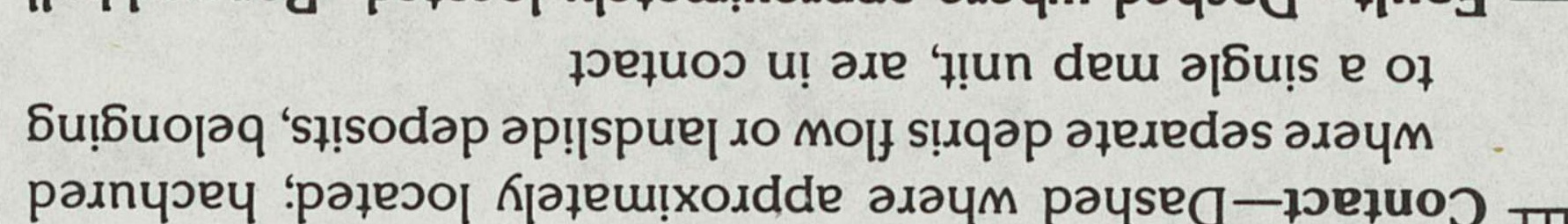

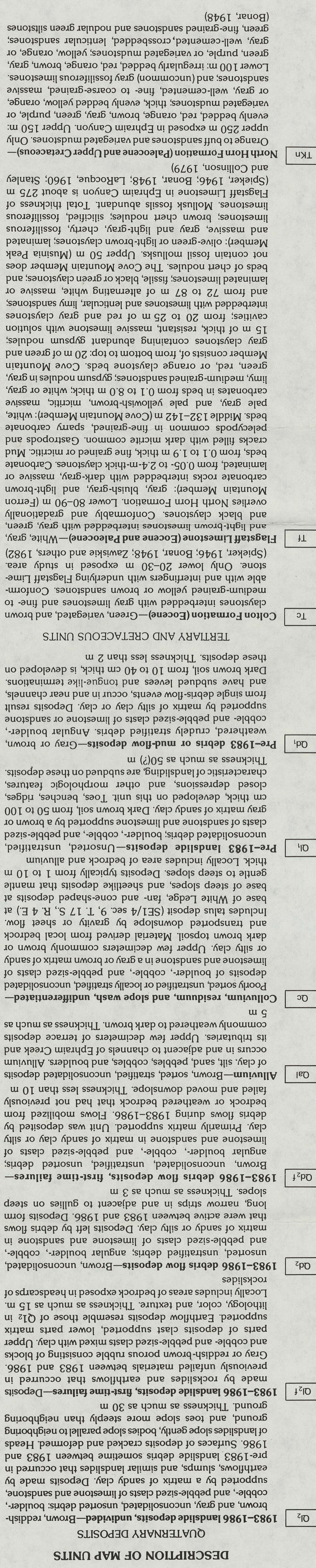

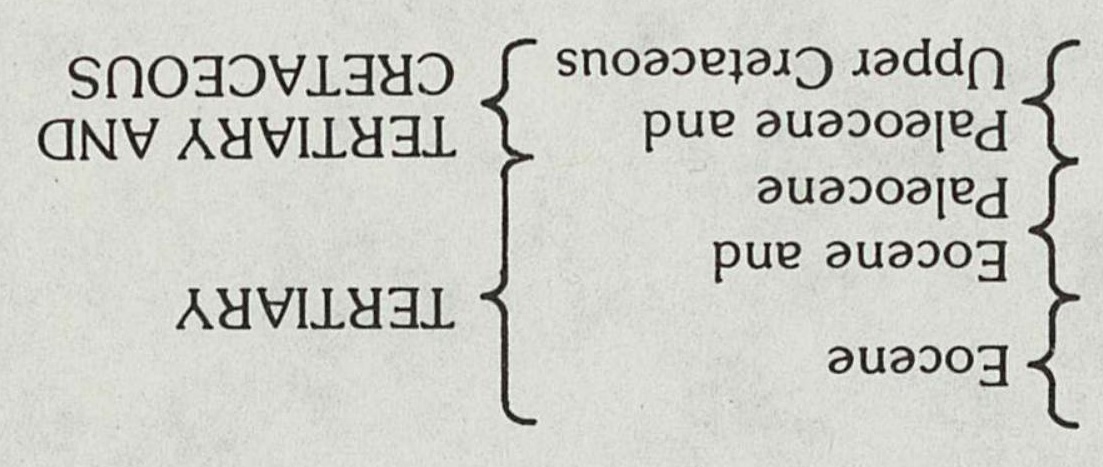

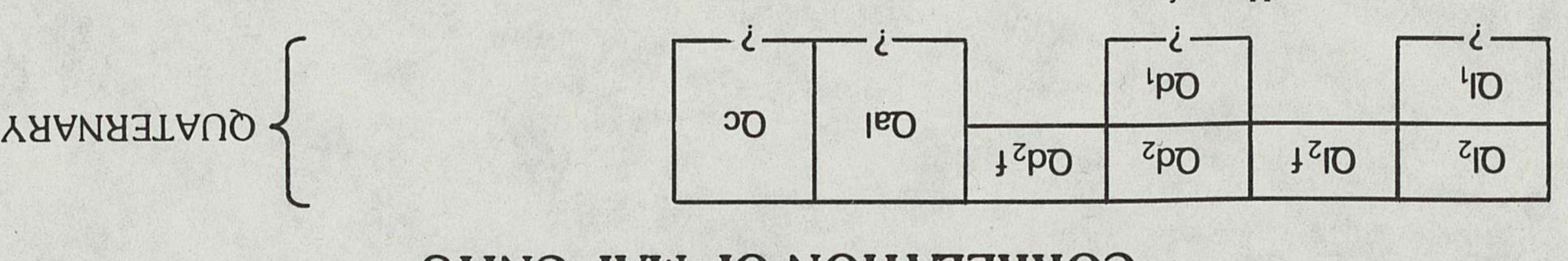

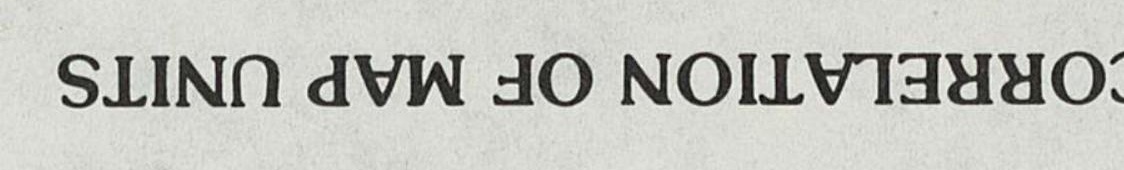












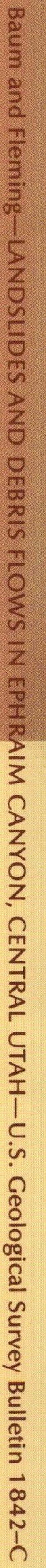

